\title{
EDUCATION THROUGH INNOVATION IN THE FIELD OF METALLIC MATERIALS SCIENCE
}

\author{
Adrian IOANA ${ }^{1, *}$, Daniela TUFEANU ${ }^{1}$, Dragos Florin MARCU ${ }^{1}$, Bogdan FLOREA ${ }^{1}$, Daniela \\ Alice LUTA ${ }^{1}$, Bianca Cezarina ENE ${ }^{1}$, Daniela Ionela JUGANARU ${ }^{1}$, Roxana Marina SOLEA ${ }^{1}$ \\ ${ }^{1}$ University Politehnica of Bucharest, Faculty Science and Engineering Materials, \\ Bucharest, Spl. Independentei 313, 060442, Romania
}

\begin{abstract}
The importance of the innovation process lies in its main functions, those of generating and leading to the conception and development of new processes and products, based on creativity. Hence the need of education for innovation. In this article we present, for a start, the main stages of an innovation process. Then, elements of innovation management, innovation strategies, innovation activities. We also present aspects regarding the financing of the innovation process and of the technology transfer. As results of the efficient application of these theoretical elements specific to an innovation process, we present the main elements of a patent (Invention Patent no. 107025/1993) of one of the authors. This patent, entitled "Burner" has gone through all stages, from conception to implementation in industry. This implementation took place in the former Special Steels Plant ok Targoviste (COST), in Electric Steel Mill no. 1 (OE1), with a good technological and economic efficiency.
\end{abstract}

Keywords: Education, Innovation, Metallic materials science, Innovation strategies.

\section{Introduction}

Education in the field of innovation is of great importance. In this regard, in the university field specific disciplines are assigned, such as: Innovation Management, Project Management etc.

However, this is insufficient. Education should start much earlier, in the primary cycle. The discipline "Technological Education" should have this role, to form and develop the spirit of innovation, novelty. It doesn't really fulfill this role. Unfortunately, even in the field of scientific research, especially in the applied research, at any level, innovation is not at a very high level. The whole process should start much lower, at the primary level.

In this article we aim to present the primary elements of the conception and realization of a paten, including aspects of implementing an invention.

According to the paper "Innovation Management", “...innovation is not an uncontrollable force, linked exclusively to inspiration and creativity, it is not the prerogative of certain elite companies, and does not depend on magic formulas, accessible only to certain organizations; it's about good management."

The public institution that manages the innovation process in Romania is the State Office for Inventions and Trademarks (OSIM). Its declared mission is: „The mission of the State Office for Inventions and Trademarks (OSIM), the sole authority in Romania in granting the protection of industrial property, is to support innovation, competitiveness and profitability as factors of economic growth." 
OSIM provides quality specialized services by granting industrial property rights, promotes industrial property through all channels and means and ensures Romania's cooperation in international relations, in accordance with the treaties, conventions and agreements in the field, to which our country is a party. "

Is that perhaps enough? We don't think it is! What would be particularly useful are actions and activities of mass popularization of the invention activity, including introductory courses in invention organized in schools, high schools, even universities. Apart from that, exhibitions presenting spectacular inventions would be useful as well.

\section{The stages of a patent conception and creation}

Any innovation process must have the development of new products and processes based on creativity as a starting point.

During the innovation process, several aspects must be taken into account, such as $[1,2]$ : organizational, commercial, technical and financial measures for the realization of a new product, or a modernization of product. It is good to remember that an invention is a novelty worldwide, and an innovation is a novelty at the local, country, even enterprise level. In the next paragraphs we will refer to inventions.

The main stages of the conception and realization of a patent for invention are the following [3]:

1. The idea. This must take into account the desired, expected development or modernization. It is recommended to write the idea down, as it can come up in unexpected moments and it can be easily forgotten. Therefore, according to the Latin saying "scripa manet", it is good to write it down.

2. Documentation in the field. The documentation must be thorough and from several sources such as: specialized literature, books, articles, already existing patents. The Office of Inventions and Trademarks (OSIM) offers the advantage of a rich library of patents. Before starting to design and write the file for the patent application, it is mandatory to consult as many patents in the field, ideally all. This way you can make sure that your idea does not lie in an already existing patent.

3. Drafting the file for patent application. This file is relatively simple, contains an application, a summary of the invention, a description and the claim (or claims). In this description, starting from the initial stage in the field (hence the great importance of the documentation stage) presented through 2-3 examples, you should move on to the invention description, including figures, relationships, etc. It is very important to highlight and argue the advantages that the new invention brings, compared to the existing ones, so compared to the current stage. Finally, the claim (claims), ie what is required as an element of novelty. A patent application may have several claims, or an invention may be "broken" into several inventions, each with different claims. You should know that it is not mandatory (but desirable) for the requested invention to be described as applicative, it can have only a theoretical character. What is very important is that it contains elements of novelty worldwide.

4. Submission of the patent application file to OSIM. You will receive a registration number, with the date and time of submission. From that moment on, your idea is protected in terms of copyright.

\section{Innovation models}

According [1, 4], the new paradigms of innovation compared to the traditional model are "Open innovation" and "Closed innovation". These are the expressions Chesbrough attributes to the two approaches. We will present and briefly analyse each of them in the following paragraphs. 


\section{Open innovation}

Open innovation defines a new philosophy for the research-development-innovation cycle, which involves combining different sources of internal and external ideas, as well as ways to capitalize on new products and technologies [5-7].

In Fig. 1 we present the scheme of the open innovation principle.

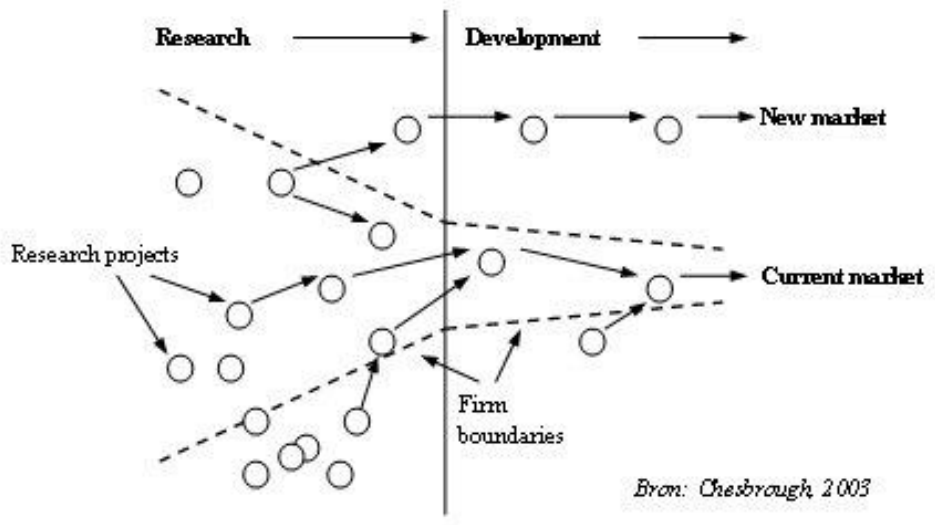

Fig. 1. Outline of open innovation principle

The concept initiator perceives open innovation as "a paradigm that assumes that companies can and should use external and internal ideas, as well as internal and external ways to capitalize on the market, so as to develop their technologies" [1]. Open innovation represents "the use of knowledge inputs and outputs to accelerate internal innovation, respectively the expansion of markets for the external use of innovation".

\section{Closed innovation}

Closed innovation defines the traditional model of achieving innovation, successfully applied for a long time, by companies that have managed to outperform their competition by capitalizing on the results of their own research and became market leaders. The basic characteristic of this model is the high degree of integration of research, development and innovation activities, both the generation of new ideas as well as their development and capitalization on the market being carried out within the same organization.

In Fig. 2 we present the closed innovation scheme, characterized by the development of the research-development-innovation flow between the company's borders.

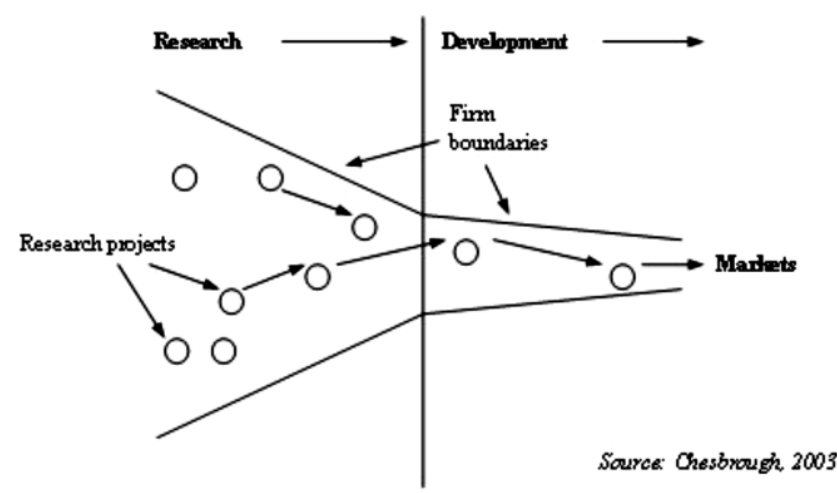

Fig. 2. Outline of closed innovation principle 
The process can be seen in the form of an innovation funnel, with a large number of ideas and concepts at the entrance, from which are selected and developed only those that best meet the company's requirements.

\section{Results and discussions regarding a patent}

\section{Burner - Patent no. 107025/1993}

The operating principle of self-contained recovery burners is based on preheating the combustion air right in the burner body (designed in the form of a heat recuperator), by taking over a part of the physical heat of its own hot flue gases [3]. Fig. 3 presents the principle diagram of the recovery burner.

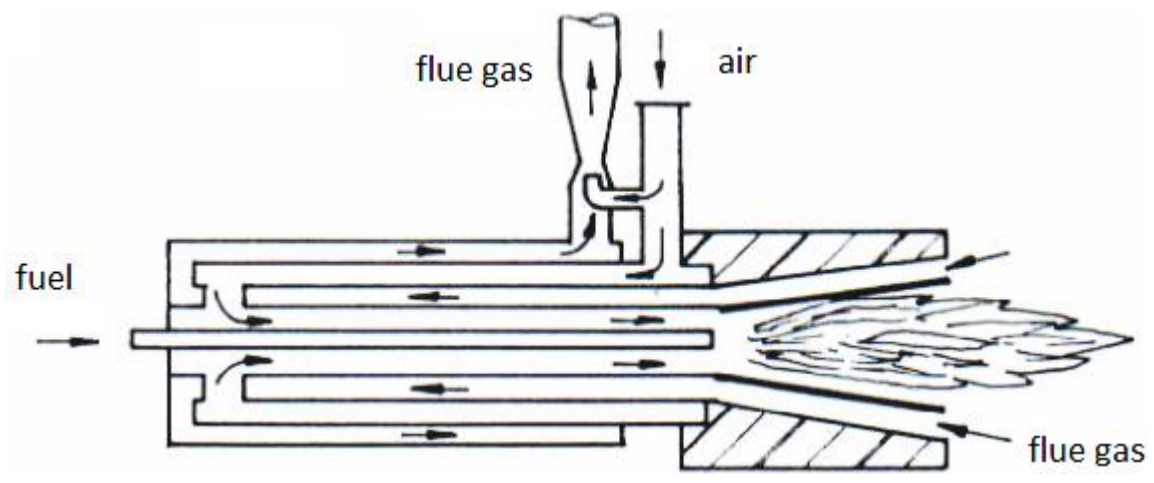

Fig. 3. Schematic diagram of the self-contained recovery burner

The preheating of the combustion air in the body of the recuperative burner is done following a primary energy recovery process, which leads to the increase of the energy efficiency of the heating process of the casting pots. Table 1 presents some data on the recovery burners that are currently operational in the country.

Table 1. The main functional parameters of the self-contained recovery burners

\begin{tabular}{ccccccc}
\hline $\begin{array}{c}\text { Nr } \\
\text { crt }\end{array}$ & $\begin{array}{c}\text { Nominal } \\
\text { termic } \\
\text { power }\end{array}$ & $\begin{array}{c}\text { Nominal } \\
\text { natural } \\
\text { gas flow }\end{array}$ & $\begin{array}{c}\text { Normal } \\
\text { natural } \\
\text { gas } \\
\text { pressure }\end{array}$ & $\begin{array}{c}\text { Pot } \\
\text { capacity }\end{array}$ & $\begin{array}{c}\text { Temperate } \\
\text { combustion } \\
\text { air }\end{array}$ & $\begin{array}{c}\text { Temperate } \\
\text { masonry } \\
\text { pot }\end{array}$ \\
\hline 1 & $(\mathbf{k W})$ & $\left(\mathbf{m}^{3} \mathbf{N} / \mathbf{h}\right)$ & $(\mathbf{P a})$ & $(\mathbf{t})$ & $\left({ }^{\circ} \mathbf{C}\right)$ & $\left({ }^{\circ} \mathbf{C}\right)$ \\
\hline 2 & 100 & 10 & 6000 & 3.5 & 500 & $700-800$ \\
3 & 250 & 16 & 8000 & 7.5 & 500 & 800 \\
4 & 400 & 40 & 7500 & 7.5 & 495 & $850-1100$ \\
\hline
\end{tabular}

Fig. 4 presents the composition of a vertical drying and preheating stand, equipped with a recovery burner of its own design. 


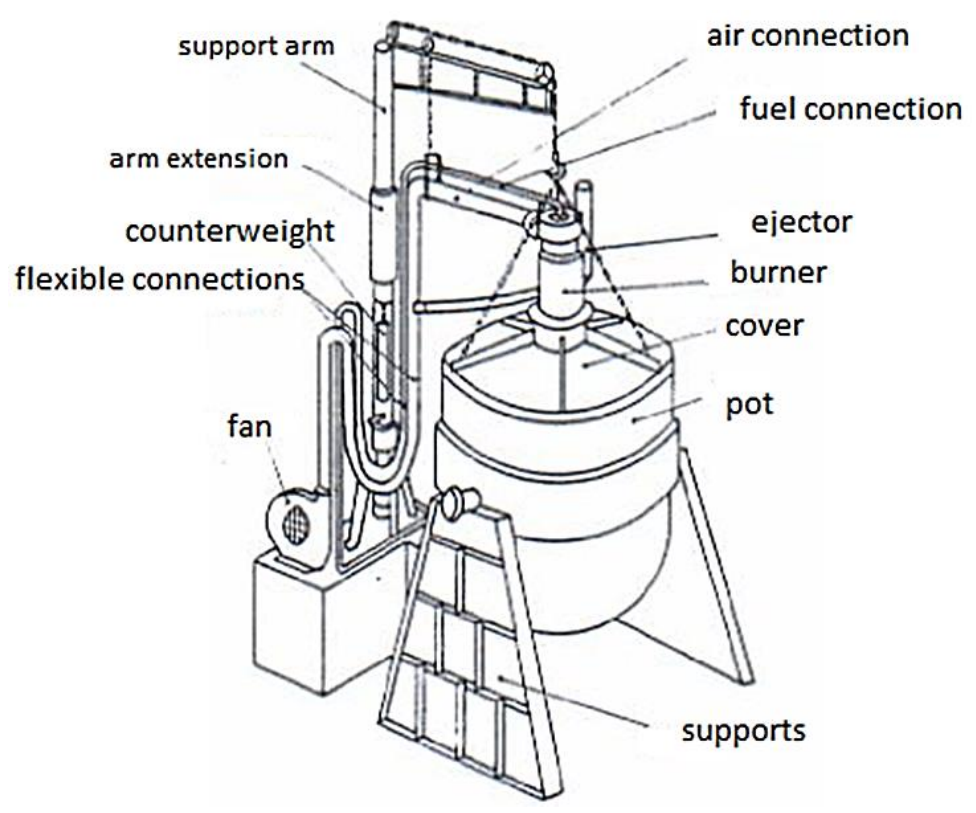

Fig. 4. Drying and preheating stand equipped with a self-contained recovery burner

The main results obtained by implementing the recuperative burners within the drying and preheating installations are:

- increase of approx. 4 times the productivity of the drying and preheating operation (LUGOMET S.A. Lugoj)

- increasing the preheating temperature of the casting pot from $700 \ldots 800^{\circ} \mathrm{C}$ to $1000 \ldots$ $1100^{\circ} \mathrm{C}$, necessary for the VOD pot (COS -S.A. Târgovişte);

- reduction of fuel consumption (natural gas) by $20 \ldots 30 \%$ (COS S.A. Târgovişte, LUGOMET-S.A. Lugoj, CIOCANUL S.A. Nădrag).

\section{Conclusions}

Education for and in the spirit of innovation is of particular importance for the healthy development of an economy. That is why this process must start at an early age and continue at all levels of education.

Among the stages of the process of invention conception and elaboration (all very important by the way), we notice the first stage, the idea. The history and genesis of many inventions has shown that often the idea comes as a matter of chance. It can pass you by without you perceiving it. Here comes into play the importance of innovation education, instilling passion for novelty.

It is desirable, but not mandatory, for an invention to have a practical applicability, to produce a beneficial economic effect. However, the invention can exist only at a theoretical level. It can often produce beneficial effects over time (for example, the theory of relativity).

The invention presented in this article refers to a recuperative burner that was applied in the metallic materials industry, for drying and preheating steel casting pots. The economic effect of this invention was obvious: reducing fuel consumption (natural gas) by about $30 \%$, improving the technological parameters of the drying and preheating process (decreasing the duration, increasing the value of the preheating temperature). 


\section{References}

[1] Chesbrough, H., The Era of Open Innovation. In: Magazine Spring 2003, Research Feature April 15, 2003

[2] Ioana, A., Noi Descoperiri, Noi Materiale, Noi Tehnologii, Printech, ISBN 978-606-230069-2, Bucureşti, 101 pag., 2013.

[3] Ioana, A., Gaba, A., Pãunescu, L., Burner, Invention Patent no. 107025/1993, OSIM, Bucharest, 1993.

[4] Casey, M., Hackett, R., The 10 biggest R\&D spenders worldwide, http://fortune.com/2014/11/17/top-10-research-development.

[5] Cook, Ph., Strategies for Regional Innovation Systems: Learning Transfer and Applications, United Nations Industrial Development Organization, Vienna, 2003.

[6] Cooper, G.R., Stage-Gate Systems: A New Tool for Managing New Products. In: Business Horizons / May-June 1990, p.44-54.

[7] Dan, M.C., Clusterele inovative: o soluţie pentru dezvoltarea economică a României. In: Economie teoretică şi aplicată, Volume XIX (2012), No. 9(574), p.3-14.

Received: March 03, 2021

Accepted: April 02, 2021 